\title{
Groundwater as a strategic resource for improved resilience: a case study from peri-urban Accra
}

\author{
Jenny Grönwall ${ }^{1}\left[\right.$. Sampson Oduro-Kwarteng ${ }^{2}$
}

Received: 28 June 2017 / Accepted: 16 December 2017 / Published online: 22 December 2017

(c) The Author(s) 2017. This article is an open access publication

\begin{abstract}
Water insecurity is a growing concern globally, especially for developing countries, where a range of factors including urbanization are putting pressure on water provisioning systems. The role of groundwater and aquifers in buffering the effects of climate variability is increasingly acknowledged, but it can only be fully realized with a more robust understanding of groundwater as a resource, and how use of it and dependency on it differ. Accra and its hinterland exemplify an African city with chronic water shortages, where groundwater resources offer opportunities to improve resilience against recurring droughts and general water insecurity. Based on a mixed-methods study of a peri-urban township, it was found that for end users, particularly poor urban households, resilience is an every-day matter of ensuring access from different sources, for different purposes, while attention to drinking water safety is falling behind. Planners and decision makers should take their cue from how households have developed coping mechanisms by diversifying, and move away from the focus on large infrastructure and centralized water supply solutions. Conjunctive use, managed aquifer recharge, and suitable treatment measures are vital to make groundwater a strategic resource on the urban agenda.
\end{abstract}

Keywords Groundwater management $\cdot$ Resilience $\cdot$ Coping $\cdot$ Conjunctive use $\cdot$ Peri-urban $\cdot$ SDG 6.1/6.6/9.1, Accra

\section{Introduction}

Risks to universal drinking water security are accelerating. In sub-Saharan Africa (SSA), a major challenge comprises of negative trends in piped water access on premises in urban areas (Hope and Rouse 2013). Cities represent complex systems, where the water needed for growth and development depends on both local hydrologic conditions and the physical and institutional mechanisms by which water resources are procured and managed (Padowski et al. 2016). Today's urbanization process is expected to result in two-thirds of the global population living in cities by 2050, and where people live is a powerful determinant of how they live with respect

Jenny Grönwall

jenny.gronwall@siwi.org

Sampson Oduro-Kwarteng

sokwarteng@gmail.com

1 Stockholm International Water Institute (SIWI), Box 10187 , SE-100 55 Stockholm, Sweden

2 Regional Water and Environmental Sanitation Centre, Kwame Nkrumah University of Science and Technology (KNUST), Kumasi, Ghana to access to basic services such as water and sanitation, as well as their environmental footprint and vulnerability to natural hazards (UN DESA 2015). More recent progress toward achieving the Millennium Development Goal (MDG) target of halving the proportion of people without access to improved sources of water attests to the uneven development of urban areas. As authorities tend to focus on meeting water needs of large cities through infrastructure expansion and supply augmentation while the needs of peri-urban locations receive scant attention (Narain 2014), informal, unplanned settlements end up with the lowest basic service levels. In SSA, which is falling behind in urban water provision, some $55 \%$ of the urban population live in such areas (UN-Habitat 2016). While the formal sector continues to idealize the notion of the "modern infrastructure ideal" based on piped networks, community-based supply—characterized not least by abstraction from shallow wells-is the main water source in urban areas of many developing countries (Kooy 2014; Liddle et al. 2016).

Shallow, hand-dug wells are often microbially contaminated due to their placement and insufficient source protection including inadequate wastewater handling and solid waste management; a major challenge therefore remains in raising 
awareness connected to risks of consuming untreated groundwater from such (Akple et al. 2011; Lapworth et al. 2017; Okotto et al. 2015). Nonetheless, in SSA groundwater is the major source of drinking water and has an important role in improving health and sustaining urban livelihoods (Adelana et al. 2008; MacDonald et al. 2012). Interest in the role of groundwater has grown rapidly recently, but management of it has not featured strongly in national and regional African water agendas (Braune and Xu 2010), despite it being a critical underlying resource for human survival and economic development in extensive drought-prone areas across SSA, including for urban water supply (Foster et al. 2012). The resilience concept is only just beginning to be applied to groundwater (Foster and MacDonald 2014), leaving many questions to be explored in terms of what this conceptual lens can mean.

This paper aims to put a spotlight on the role of groundwater as a strategic resource, on the one hand for actual coping with inadequate drinking water services, as developed at household level, and on the other hand for a city's short- and long-term planning to improve resilience to water shortage and periods of drought in the face of urbanization and climate change. This is illustrated with a case study of Ghana's capital city Accra with focus on a township at its fringe, Dodowa, which was entirely groundwater-dependent until the end of 2014, and whose aquifers previously served other parts of Greater Accra. Groundwater thus fills, or used to fill, a part of the water demand-supply gap, but its potential is neither formally recognized nor fully explored at present. It is therefore relevant to ask whether this resource could be of greater importance to respond to growing water security risks, thereby improving resilience.

Following the methods and analytical framework section, we describe how the dependence on groundwater has changed over time in Dodowa and Greater Accra, respectively, noting that sachet water plays a role in this transition. We then make the case for how improved urban water security and resilience depend on governance that recognizes the importance of conjunctive use and plans for enhanced buffer capacity based on diversification to spread risks. The end users' coping mechanisms are considered in terms of availability, water safety and equity. In conclusion, this paper points to three lessons for improved social-ecological resilience based on the case of Dodowa.

\section{Methods and analytical framework}

\section{Methods}

This paper builds on secondary sources and a case study of Dodowa, a low-income township of some 12,000 people on the outskirts of the Greater Accra region, some 30 kilometers from the coast (Fig. 1). Dodowa was selected for investigation of groundwater matters as part of a larger study of unplanned urban areas in Ghana, Uganda, and Tanzania under the Unlocking the Potential of Groundwater for the Poor research programme (UPGro.org).

Primary data were collected during field work using a mixed-methods approach. In October 2015, observations of well structures, water access points and storage infrastructure, rainwater collection, etc., were made during meandering walks through Dodowa's different areas. Semistructured, open-ended interviews were conducted with 35 purposefully selected residents, representing a variety of water access conditions and experiences. Key informants at the public water utility, the District Assembly, and the Water Resources Commission, as well as researchers at the University of Ghana, Legon, and representatives of three mineral water companies in Dodowa were also interviewed on their views of groundwater as a strategic resource. Further interviews in October-November 2016 focused on the mineral water companies in Dodowa, and the impact of the water utility's tariff amendments.

Together with the local research team, a householdlevel survey of 300 respondents was conducted in Dodowa in October-November 2015. Systematic sampling was done at every fifth household. The Microsoft Excel and SPSS Statistics programmes were employed for analysis of the data and to develop descriptive statistics used to summarize information such as respondents' access to water from a variety of sources and reasons behind different choices (described in Grönwall 2016).

\section{Analytical framework}

The pursuits of augmenting safe water access and "climate-proofing" cities (making them more able to withstand floods, droughts, or a range of other natural disasters), form parts of the urban agenda advocating resilience-building-yet, 'resilience' is still discussed in the scientific community against a relative lack of understanding of how to operationalize the metaphor (Caputo et al. 2015; Chelleri et al. 2015; UN-Habitat 2016). Here, resilience is defined as the "capacity of a system to absorb disturbance and reorganize while undergoing change so as to still retain essentially the same function, structure and feedbacks, and therefore identity, that is, the capacity to change in order to maintain the same identity" (Folke et al. 2010). This understanding of social-ecological resilience considers people and nature as complex and interdependent systems, in turn relying on adaptability and transformability across multiple scales (ibid). It follows that a resilient city is one where managers and decision makers plan and design for constant adaptation needs by taking into account how growth is organic, unforeseen, and 
GHANA MAP

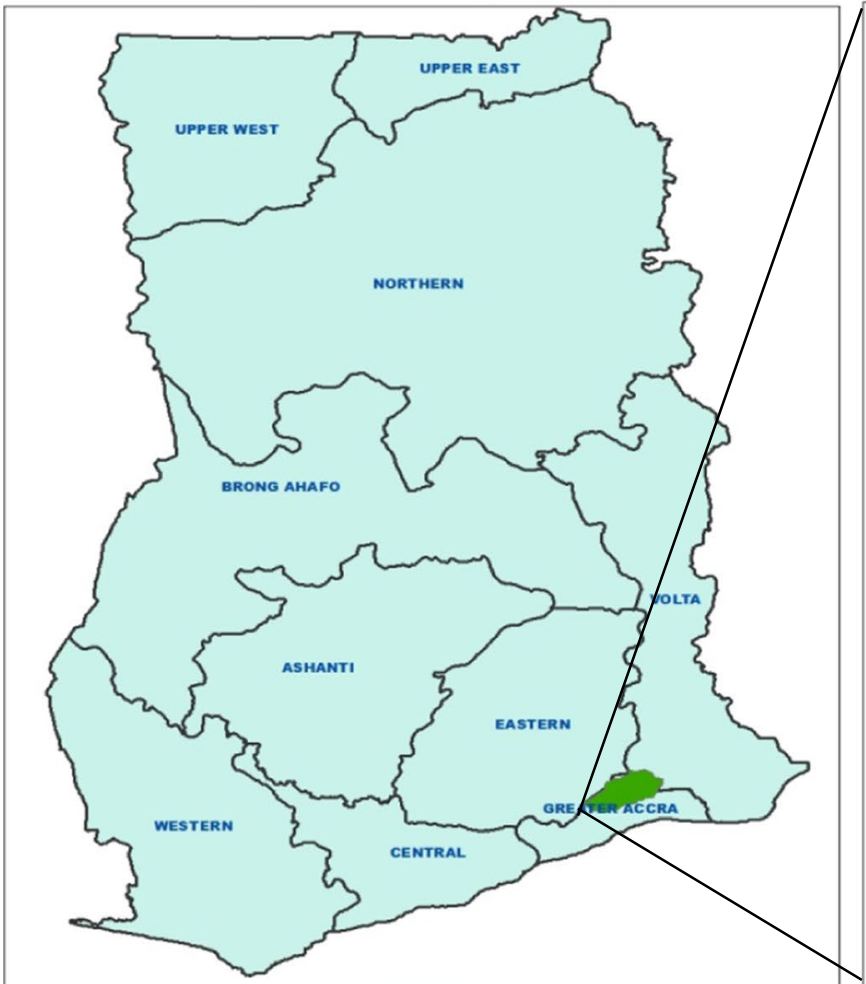

MAP OF SHAI-OSUDOKU DISTRICT SHOWING DODOWA

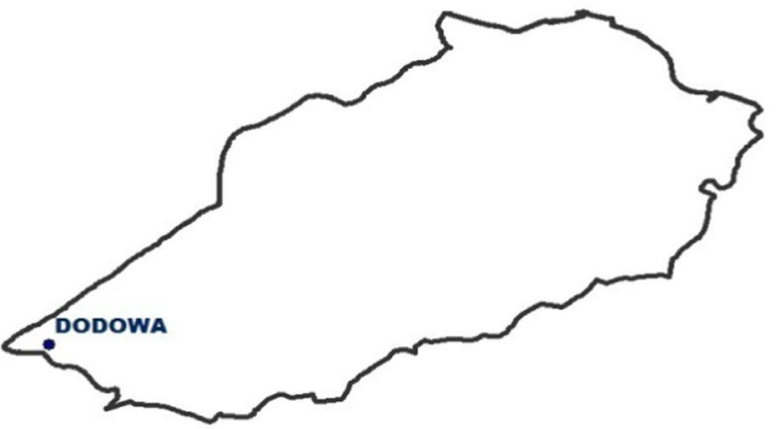

Fig. 1 Ghana, Greater Accra, Shai-Osudoku district and the location of Dodowa

characterized by nonlinearity, and by building flexibility into processes, while recognizing that there are unknowns in terms of natural resources and ecosystems' responsiveness. At a smaller scale, a resilient household is one that can self-supply from different water sources to increase its capability to cope with stress, with respect to quantity (access, availability) as well as quality issues (health and safety).

No city is an island, and situating Dodowa in the larger picture of Greater Accra serves to highlight how a city and its hinterland are often intrinsically linked in terms of the resource base, as well as decision making systems of relevance for sourcing and distribution of water. The literature highlights the importance of a city leaving behind the idea of being self-supporting, and the risks associated with relying heavily on an engineering, technology-driven conceptualization of resilience, pointing instead to how attempts at managing variability to reduce vulnerability may lead to lock-in with large-scale infrastructure such as dams (Caputo et al. 2015; Muller 2007).

\section{Past and present dependence on groundwater in Dodowa and Accra}

\section{Transition from self-sufficiency in local groundwater resources}

Accra and its hinterland exemplify an African city with chronic water shortages, where residents are accustomed to implementing a host of coping strategies in response to the public utility's inability to provide water to everyone, struggling and "chasing" for water from a multitude of sources (Peloso and Morinville 2014). The poor are particularly disadvantaged in terms of public service delivery and often rely instead on groundwater from communal wells or through self-supply, a solution seen particularly in peri-urban Accra (Grönwall 2016; Machdar et al. 2013). Being a coastal city, seawater intrusion restricts the use of groundwater in large parts of Ghana's capital. However, at $30 \mathrm{~km}$ from the coastline, Dodowa does not suffer from this problem. The township is located in the foothills of the Akwapim-Togoland mountain ranges at the northwestern fringe of the Accra Plains, large parts of which is an aquifer recharge area. The mountain range serves as a watershed, and accounts for a micro-rain shadow effect that influences the climate of Dodowa and its immediate surroundings. Mean annual 
rainfall increases from $762 \mathrm{~mm}$ on the coast to $1220 \mathrm{~mm}$ in the north and northeast close to the mountain range. This part of Ghana is one of the hottest and driest areas of the country. Dodowa is built on strongly metamorphosed ancient sediments characterized by weathered and fractured metamorphic rock (quartzite and gneiss, on the NW-SW and NE-SE, respectively). Most fractured aquifers are found in the gneiss, thus in the eastern part of the township (GSS 2014; Kortatsi 2006).

Like most urban areas globally, Accra and Dodowa are undergoing transformations. As the capital of the Shai-Osudoku District, formed in 2012, Dodowa is witnessing rapid growth primarily due to immigration from rural parts of the country and from Accra proper, and with the latter comes gentrification. An important set of changes relate to the provision of water. The Ghana Water Company Ltd. (GWCL 2016) is responsible for water supply in the country's urban areas-but administratively, the township of Dodowa, at the fringe of Greater Accra, also falls under the Community Water and Sanitation Agency that is in charge of rural areas and small towns. Hence, in parallel with the GWCL, this agency, alongside with the Shai-Osudoku District Assembly (SODA), still assumes a certain level of responsibility for Dodowa's water provision. However, rather than ensuring that residents are well-provided for, those accountable for water supply and related governance issues remain unresponsive to strategic planning needs (Grönwall 2016).

The GWCL supplies water via domestic connectionsfully private ones indoors, or shared ones in the compound or inner yard. The company levies an estimated cost for every new installation; the minimum charged according to an old study (Franceys and Gerlach 2006) was GH $\not 150,000$ (ca. USD 33,275), a prohibitively high cost. Communal solutions, through which the majority of water users have access, include public standpipes and resellers with taps categorized as 'commercial'; at both one often finds polyethylene storage tanks with taps and an attendant charging on a pay-and-fetch basis. A normal price is around $\mathrm{GH} \phi 0.40-0.50$ per jerry can à 1 gallon (ca. $4.5 \mathrm{~L}$ ), while a customer with a domestic connection contract pays substantially less $(\mathrm{GH} \notin 2.98$ for $\left.0-5 \mathrm{~m}^{3}\right)$.

In areas where the pressure in the GWCL network is poor, or the water supply otherwise insufficient, SODA provides water from communal boreholes. In recent years, the assembly has constructed five new ones following requests from users in Dodowa. The water provisioning alternatives for residents of Dodowa are summed in Table 1.

According to our household survey, $47 \%$ of respondents accessed water at a public standpipe or commercial tap, while $21 \%$ had access to piped water into a building or yard. Altogether, 57\% had GWCL water as their main source. However, 55\% of respondents also reported having a second source as a back-up or to complement the first. Groundwater plays a major role in Dodowa; most respondents (78\%) use it as their main and/or secondary source, accessing it from any of the area's 37 dug wells and 20 boreholes. The latter are fitted with a hand or foot pump, or are motorized. While a couple of 'community wells' dug in the 1960s are still in use, it is more common that dug wells are installed and maintained by (groups of) families, serving especially poor households. Observations in the area also suggest that a hitherto slow but visible gentrification results in more private, motorized boreholes. It may be that this transformation of Dodowa is taking place partly because of the easy access to groundwater at the outer fringes of the capital city, as advertised by real estate agents. The water table is generally very shallow at a few meters below the surface of the ground, enabling poor households to obtain water from dug wells. The cost of drilling and developing a borehole is relatively low at about GH $\not 15,000$ (ca. USD 3,500).

The GWCL previously abstracted water from six boreholes in Dodowa and distributed it through the local network to customers and standpipes. Today, the utility instead sources its water from the Volta River via the Akosombo

Table 1 Water sources and providers in Dodowa Reproduced with permission from (Grönwall 2016)

\begin{tabular}{lll}
\hline No. & Source & Main provider and governing body \\
\hline 1 & Piped surface water from the Kpong & GWCL \\
2 & & Own connection; into building or to yard tap \\
3 & & Resold from registered public tap/standpipe \\
4 & & Resold via neighbor (à domestic or commercial tariff) \\
5 & Bottles and sachet water & Private vendor (controlled by the food and drugs authority) \\
6 & Borehole fitted with manual or motorized pump & Assembly (SODA), community, neighbor or self \\
7 & Dug well & Assembly, community, neighbor or self \\
8 & Public tap/standpipe (often stored in 'poly tank') & GWCL (no. 3-4 above), assembly or community \\
9 & Tanker or cart (Kpong water or groundwater) & Private vendor \\
10 & Rainwater harvesting & Self \\
11 & River or stream & (Commons; self) \\
\hline
\end{tabular}


dam and the Kpong treatment plant (to the west of Accra the water comes from the Weija reservoir, fed by the Densu River). For Dodowa the change came into effect at the end of 2014 when the 'Kpong expansion intake project' was finalized. It featured a new water treatment plant, power substations, transmission pipelines, new reservoirs, pumps, and booster stations. Carried out to improve supply, it also aimed to benefit communities such as Dodowa, through which the mains pass. International companies including Siemens and China Ghazouba Group were responsible for the construction of the plant, which was partly funded by Israel and the Netherlands, and partly by a loan from the Bank of China (Government of Ghana 2016; Modern Ghana 2014).

With so-called Kpong water now available from the centralized distribution system, the GWCL stopped abstracting water from the boreholes in Dodowa by removing the pumps. During interviews for this study, some respondents expressed that they were content that groundwater was no longer provided in the network as it was very "salty" and would not let the soap lather; however, it appeared as if few were well-informed about the water they used, in terms of quality parameters or in terms of the raw water source. It also remained unclear whether Kpong water was actually only meant to supplement the local boreholes for customers in Dodowa. At GWCL headquarters there was little interest in sharing information, while a local employee opined that the good-yielding boreholes should be used again. In a phone interview, a senior SODA representative shared a personal observation: As the piped water was sometimes 'salty' in taste, this would indicate that groundwater was still occasionally supplied.

Respondents complained that the piped supply was equally intermittent after Dodowa was connected to the mains. While it may seem that SODA could have assumed responsibility for the boreholes and infrastructure from the GWCL, the way in which the utility (purportedly) discontinued the groundwater use is an example of how authorities act in silos rather than collaborate, to the detriment of end users who are not consulted.

Dodowa's aquifers used to function as a raw water source also to other parts of Accra, from when GWCL had a private operator, Aqua Vitens Rand, Ltd. (2006-2011). In 2006, five mechanized boreholes were commissioned to supplement the water supply, mainly to serve the Adenta municipality adjacent to Dodowa (Norely 2006). Having performed successful test drilling at selected sites, those boreholes, along with eight others, became operational in 2008 (Ghanaian Chronicle 2008). The then Minister of Water Resources, Works and Housing announced plans for the development of "mega watersheds" in parts of Accra, involving deep drilling to tap water from aquifers to add some $90,000 \mathrm{~m}^{3}$ a day into the Accra water distribution system (Vinorkor and Afari-Mintah 2008). For reasons never made clear, this plan was never realized, but GWCL customers in the Dodowa Water District and Adenta were supplied with groundwater from Dodowa once a week until borehole pumping was discontinued due to the Kpong expansion project. According to GWCL, average production from the boreholes in 2012 stood at $40,700 \mathrm{~m}^{3}$ a month.

\section{... to increasing dependence on packaged water}

In terms of drinking water safety for those in Dodowa who self-supply from the aquifers, the level of acceptability was found to vary greatly. Three out of four of those surveyed considered water from their main source fit to drink: $80 \%$ did not treat their water-a practice that may pose a significant health risk especially if water is taken from shallow, dug wells that are generally prone to wastewater contamination (Machdar et al. 2013; Lapworth et al. 2017). Approximately half of those who had adopted a 'treatment' method said they let the water stand and settle. Chlorine, alum, or other chemicals were used by the other half. However, among the survey respondents, $96 \%$ said that they bought sachet water, while a third bought bottled water. Though inconclusive in this respect, our empirical findings indicate that few respondents resorted to sachets and/or bottled water as their only source of drinking water.

That Dodowa's rich and poor alike turn to sachet water for drinking mirrors development across West Africa. Those 500-mL polypropylene sleeves, heat-sealed at both ends, are one of the go-to solutions with the most rapid uptake. Bottles and 20-liter jars have been available for a considerable period, but sachets have become popular in recent decades, and have especially permeated the low-income market in Accra, mainly for reasons of convenience (Stoler et al. 2014). In open-ended interviews on this subject, it emerged that the buying of sachets had "become a strong habit" in Dodowa over the past decade, one that people can generally afford (a sachet normally costs GH $\not 0.20$; ca. USD 0.05). A vendor in Dodowa explained that sachets are "the order of the day and people can afford it" and an elderly man held that "pomposity drives human beings to pay for sachet water. People have got more money today, they want to show off". It has been found from in-depth studies of various parts of Accra that demand is also strongly linked to the public utility's inability to provide reliable services (Peloso and Morinville 2014; Stoler et al. 2015).

However, of those surveyed in Dodowa, 60\% explained that they perceived sachet water as cleaner or safer, while a third referred to taste as a reason to buying it. It is noteworthy that the general image of Accra's groundwater is that it is unfit for drinking. Key informants in the city, representing authorities and academia, explained that it contains too much bacteria and salt (from seawater intrusion) to be used for human consumption (cf. van Rooijen et al. 2008). Among 
respondents and interviewees in Dodowa itself, the views on the 'salty' taste were inconsistent, which can in turn be due to personal preferences but also on where in the township the groundwater is obtained. As found by the local research team, several wells and boreholes have high electrical conductivity (up to $5000 \mathrm{uS} / \mathrm{cm}$ ), indicating salinity from natural geological sources and/or human activity. In those areas, sachet or bottles may be good alternatives to treatment prior to consumption through, for instance, chlorination, UV/solar disinfection, or reverse osmosis (RO) treatment to ensure safe drinking water (cf. Machdar et al. 2013; Wright et al. 2016), but such methods tend to be costly and hence out of reach of the poor.

Though most of what is packaged in sachet bags sold in Greater Accra is treated GWCL water that undergoes various steps of additional purification (Arku 2016; Stoler et al. 2012), some companies source their raw water from boreholes. Back in the late 1980s, the potential for spring and mineral water production was assessed in Ghana, with promising prospects identified along the foothills of the Accra Plains (Kortatsi 1994). Indeed, three companies - all set up within the past 5 years - are currently abstracting, treating, packaging and selling groundwater from the northeastern part of Dodowa. According to company informants, the boreholes that are in use at each yield water from a depth ranging between 20 and $60 \mathrm{~m}$. It is filtered through RO membranes as one of several steps to treat it, and the premiumpriced bottled water is subject to more treatment than that packaged in sachets. The company representatives had no comprehensive picture of the chemical quality of the raw water and what treatment was optimal; however, our first measurements indicated total dissolved solid (TDS) values in the order of $120 \mathrm{mg} / \mathrm{L}$ near the mountain foothills, which is a low concentration that should render good-tasting water (cf. WHO 2003).

\section{Groundwater availability}

What groundwater resources are available for abstraction for sustainable human use depends on local recharge and natural discharge to springs, river flows and ecosystems. Globally, groundwater withdrawal for drinking water is small in comparison with the volumes used in the agricultural sector, given that humans consume at most up to a few liters per day. In Dodowa, the decision to cease with the distribution of groundwater from boreholes should have resulted in a decrease in the volumes abstracted from local aquifers, improving the resource availability for those still depending on them.

Dodowa's mineral water companies — which provide job opportunities as well as safe drinking water for those who can afford it-are controlled only in terms of the quality of their product, by the Food and Drugs Authority. The
Water Resources Commission (WRC) of Ghana is tasked with management and regulation of the country's freshwater resources and administrates water rights under the Water Use Regulations, 2001, and the Drilling Licence and Groundwater Development Regulations, 2006, but a WRC representative informed us that its capacity to monitor or play a proactive role with respect to groundwater resources is very limited. Permits to, for instance, mineral water companies are therefore generally approved and renewed without the desired level of evaluation. The mineral water companies would have approached SODA, as well as the traditional chief, ahead of establishing a well. In the case of the latter, the need for consultation arises from the fact that by cultural practice one must see the chief to request permission to settle within his community. All chiefs in a district are also part of its assembly, each having one vote when approval is given on how much water can be abstracted.

Companies in Dodowa do not monitor total abstraction volumes with meters or sub-meters but have daily production targets. One respondent said that the average total output of bottles and sachets from his company amounted to approximately 45,000 liters per day. With RO membranes in use, the equivalent of up to three times as much water is used in processing the final product, because brine is rejected as part of the membrane treatment process. Calculated for industrial bottled water production in India, which may be comparable with that of Ghana, operational water use is, on average, 2.9 L of water per $1 \mathrm{~L}$ finished product (Tandon et al. 2014).

The total pressure on local aquifers because of packaged water production is not clear, but from figures obtained it is negligible at present. No measures for aquifer recharge were taken by the companies; this was considered unnecessary as the boreholes were always yielding. While some of the $\mathrm{RO}$ reject is reportedly used for flushing toilets, what is left over from the process is either evaporated or returned to local aquifers through irrigation and subsequent infiltration, either within the company's premises or after having been channeled to adjacent farms. Thus, though recharge does not take place in a 'managed' way, it should still be beneficial to local aquifers.

Much in line with how groundwater was dismissed by experts in Accra on grounds of its quality generally being inferior, it appeared that no one had a comprehensive picture of the abstraction situation in Dodowa or elsewhere. The SODA representative interviewed was unaware of any groundwater abstraction in Dodowa being registered, and the WRC has no capacity to deal with, or seemingly much interest in, the resource. Furthermore, residents appeared unaware of water table fluctuations, any over-abstraction risks, or of potential benefits from (natural or 'managed') aquifer recharge. Essentially all (90\%) survey respondents reported that they harvest rainwater, and gutters could be seen at the majority of houses including those of the very 
poor, possibly reflecting how, in recent years, government officials and development partners have emphasized the role of rainwater (Owusu and Teye 2014). However, our observations made clear that this was only for storing in buckets and drums or direct consumption. Even those who remarked that the water table tends to fall in the dry season (January to February) had never considered arranging for recharge of their or the community's wells in one way or the other, and the topic of aquifer depletion was clearly not one discussed among residents or with SODA.

\section{Improved resilience hinges on management and governance}

\section{Plan for conjunctive use of groundwater}

Water insecurity is a growing concern globally, especially in developing countries, where a combination of population growth, urbanization, changing consumption patterns along with improved living standards, and climate change variability put increasing pressure on water provisioning systems. Insecurity may result from harmful events such as droughts or contamination, but also more chronic factors, including water-related diseases or unreliable water supply (Garrick and Hall 2014). Freshwater scarcity is increasingly perceived as a global systemic risk and a threat to the sustainable development of human society. Four billion people live under conditions of severe water scarcity during specific times of the year due to spatial and temporal variations of water demand and availability (Mekonnen and Hoekstra 2016). But while there is vast scope for further development and dependence on groundwater resources in SSA (Foster et al. 2012), urban water supply and security still implies large and expensive infrastructure solutions such as the Kpong project that forms part of traditional water supply management and 'modern ideal'. To counteract the risk of a lock-in effect that investment in surface water infrastructure creates, a diversifying attitude will need to permeate decision making. To ensure universal and equitable access to safe and affordable drinking water, as well as to ensure sustainable freshwater withdrawals by 2030 , to protect and restore water-related ecosystems including aquifers already by 2020 , and achieve other interrelated goals under UN's Agenda 2030, sustainable development and management of groundwater resources and groundwater-associated ecosystem services are key. In turn, this rests on understanding and valuing these resources properly. As De Wrachien and Fasso (2002, p. 1) put it, "a new holistic approach is needed. This approach includes the integrated or conjunctive use of surface and groundwater resources and takes account of social, economic and environmental factors".
The literature is witness to repeated calls over almost half a century for conjunctive use to become mainstream, arguing that it requires little in the way of special facilities (D. Todd, 1959, in Nieswand and Granstrom 1971); noting a lack of confidence in the potential of groundwater resources and in the ability of today's technology to predict their behavior (Sahuquillo 1985); stressing the complementary characteristics and behavior of surface water and groundwater (Sahuquillo 2002); emphasizing that its design requires a refined understanding of resource interconnectivity (Foster and van Steenbergen 2011); and adding that projected longer-term droughts and intense floods underscore the need, on the one hand, to store more water to manage climate extremes, and, on the other, of managed aquifer recharge (Scanlon et al. 2016). Conjunctive management of a range of water sources (aquifers, rivers, reservoirs, treated wastewater or desalination) provides a portfolio of options, and in turn more secure, flexible, and resilient supplies (OECD 2017). Many more have contributed with insights as to why it is vital not to regard surface and groundwater as unrelated systems, and how to calculate and model groundwater storage and safe yield. As noted above, GWCL has experience of conjunctive use of surface and groundwater to supplement deficit surface water availability in Greater Accra. This can easily be resumed where boreholes and pumps are already installed, and in such places that were assessed for development of well-fields in 2008 . The political will is apparently absent, though.

\section{Enhance buffering capacity}

At the least advanced level, conjunctive use simply involves drawing from surface and groundwater resources in a manner that enables diversification. Typically, this involves relying on boreholes and wells as backups. At the other end of the spectrum, it comprises of fully coordinated, cautiously balanced management and development. This includes active creation and maintenance of storage buffers in the form of groundwater banks, sustained by precipitation and natural percolation as well as rainwater harvesting and 'managed' aquifer recharge (MAR). To be fully flexible and adaptive to both climate variability and changes in demand and thereby extraction, such conjunctive use needs to be informed by an integrated approach — considering administrative borders, jurisdictions and transboundary features, as well as river basins and hydrogeological settings. In critical areas, conjunctive use may furthermore need to be combined with water demand management in the sense that not only surplus surface water should be channelled for MAR, but that re-distribution also takes place between sectors. The concept of 'sustainable yield' has re-emerged in an attempt to determine a metric that can ensure the long-term resilience of groundwater systems, but the definition is fraught 
with inherent uncertainties and the quantification poses challenges (Rudestam and Langridge 2014).

MAR is not a panacea, and it is a representative example of how groundwater-associated ecosystem services have time lags that must be estimated and accounted for (Knüppe and Pahl-Wostl 2011). Nonetheless, the resilience of an increasing number of aquifers that are subject to overextraction and depletion will depend on advanced conjunctive use and management of recharge, with a close eye on short- and long-term climate change effects on storage. Not all aquifers will respond to revival efforts: overdraft that has caused compacting of pore spaces and land subsidence often leads to permanent damage.

Human activities affect available groundwater resources by abstraction and changes to recharge rates, for example by urbanization. With respect to such resources' capability to resist long- and short-term damage, respectively, and to recover under climate change, Calow et al. (2010) distinguish between two scenarios: long-term (inter-decadal) change and shorter-term (inter-annual) 'shocks'. In the former, resilience is dominated by available groundwater storage, and larger groundwater bodies will be much less affected than smaller ones. In the short term, the resilience is likewise dominated by available groundwater storage but is also influenced by long-term average (decadal) recharge to the groundwater system which will help it recover more quickly.

\section{Build resilience into governance regimes}

In 2015-2016, the El Niño-Southern Oscillation phenomenon was associated with drought and below average precipitation in large parts of Ghana, as well as in many other parts of the world, echoing the erratic, extreme, and unpredictable weather events that climate change scenarios envisage as increasingly likely. Urban drought-risk management requires a mix of measures that together limit the probability, as well as the consequences of water shortages, and that are proactive and planned rather than reactive (Buurman et al. 2017). The water availability-related stress that city planners and managers as well as individual end users must handle on an every-day basis, and especially in a drought situation, may force adaption and change to retain functions such as water supply. While households in cities such as Accra are to a large degree already accustomed to sourcing water from a multitude of places, and possibly use it for different purposes, cities need to follow suit by diversifying.

The strategic importance of groundwater as a resource for global water and food security is likely to intensify under climate change as more frequent and intense climate extremes increase variability in precipitation, soil moisture and surface water (Taylor et al. 2013). However, the invisible character of groundwater systems still limits management and governance, much because of the yet prevailing lack of more detailed knowledge regarding groundwater availability and behavior; aquifer storage and sustainable yields; projected impacts on percolation, recharge, and evapotranspiration from climate change; and quality-related dimensions. Despite increasing access to advanced modeling, satellite data, and ground-truthing methods, current understanding is often insufficient to make well-informed, contextualized decisions about sustainable groundwater abstraction for human use. For groundwater to play a vital role in buffering the effects of water shortages, improved understanding of the interrelated dimensions of drought vulnerability must come from having a good picture of groundwater availability, demand, and development potential (cf. Calow et al. 2010).

An additional key concern is to estimate supply and demand factors behind the total economic value, to better understand the groundwater stock and flow values. The benefits obtained from groundwater vary from the economic value derived from productive uses for drinking water, industry, and irrigation, to the ecological value provided by supporting groundwater-dependent ecosystems, and the option value of storing groundwater as an insurance against future water shortages (Qureshi et al. 2012; OECD 2017).

The GWCL's decision that Accra's aquifers and boreholes were superfluous following the expansion of water distribution from Kpong may have reflected a modern supply management ideal, favouring surface water infrastructure. However, it rested on poor understanding of (the limits to) current and future reliance on groundwater. It did not seem to be based on an evaluation of groundwater quality or drinking water safety, or on assessments of raw water treatment needs or costs. Neither was the decision based on knowledge about groundwater table fluctuations or recharge projections, with and without future climate change and precipitation variability. Engineering and implementing conjunctive use - and MAR, as and when needed-requires interdisciplinary knowledge and planning capacities, but also a level of political will to redirect decision making from conventional dependence on large-scale hardware solutions, often pushed for and financed by institutions with insufficient background information. Misaligned incentives between decision makers are an additional factor behind poor water governance. As identified by Foster and Garduño (2013), the political economy is often driven by matters relating to lack of understanding of the status and dynamics of, and risks to, the groundwater-resource base, and a particular set of vested interests.

If the basic attributes of groundwater systems and their functioning are inherently difficult to grasp, at least groundwater use-where and how much is extracted over a specified period, for what purposes, by whom, under what conditions, etc. - - should in theory be possible to regulate and 
control. Ghana has the Water Use Regulations, 2001, and the Drilling Licence and Groundwater Development Regulations, 2006. Nonetheless, a regulatory framework is only a small part of the wider governance system. As in many other countries, there may already be an adequate legal code to control groundwater use, if less so for groundwater-pollution protection (cf. Foster and Garduño 2013) - but in a case study on groundwater governance and regulatory compliance, Cohen and Bakker (2010) have shown that local regulations (and decision making) cannot easily incorporate scientific research, and in turn result in sound on-theground management. Furthermore, sound on-the-ground management seldom translates into effective enforcement at the local level. There is often a lack of "biophysical fit" between applicable legislation and environmental characteristics, resulting in tensions between standards for regulatory uniformity and the need for flexibility that raise questions regarding what scale and level of decision making is best equipped to deal with highly contextualised matters (ibid). An example of this is how aquifer conditions are rarely uniform within a geographical area, meaning that a onesize-fits-all approach is inadequate to regulate for all circumstances. Dodowa itself is a case in point, with relatively low-yielding quartzite underlying the most inhabited areas, and mineral water companies set up in the northern part. If the latter is the more productive, it is reasonable to assume that it will be of greater interest in the future not only for real estate agents and Dodowa's new and wealthier land owners, and those manufacturing packaged drinking water. To preserve groundwater as a common good, the private sector's extraction may soon need to undergo more far-reaching control, with permits to be subject to context-specific conditions to recharge local aquifers, and monitor the volumes pumped and consumed. However, without more in-depth data from assessments, it will be difficult to judge the volume of a sustainable extraction, and how resilient natural systems are to disturbance.

\section{Raise end users' resilience}

At the time of the study, the expanded Kpong water project had failed to provide better access, more affordable water, and improved availability as in comparison with what it replaced. In these respects, water users in Dodowa were seemingly not better off than before. For most residents of this township the result of the GWCL shifting to surface water seemed a zero-sum game; they had to continue chasing for water for their various needs from many different sources, and storing it at home. They were also still in dire need of the local groundwater resources in one way or the other; because the piped water supply is irregular, available only at a great distance or at certain times and days in the week, and/or perceived as unaffordable. In addition, many people in Accra, including those from poor households, could have benefitted from groundwater being pumped and distributed from the aquifers in Dodowa and elsewhere along the mountain range where the recharge conditions contribute to making the utilization of this resource relatively sustainable.

Poverty defines water access for a very large number of households in Dodowa, as it does elsewhere in Greater Accra and numerous other cities in SSA, but coping strategies are different for many peri-urban dwellers here because they include self-supply from own or shared wells and boreholes. Water safety aside, the residents of Dodowa are thus relatively fortunate, and, with the exception of some dug wells that tend to dry up during the dry season, water security is high. Water availability, as close to the home as possible, has earlier been shown to be more important than improvements in water quality as increased water supply can improve health status by enabling better hygiene (Esrey et al. 1991), but appropriate treatment of water, at pointof-use in those cases it is stored at home because supply is intermittent, has later been found to be more effective than previously thought (Fewtrell et al. 2005). It is not clear from our study how many people-if indeed any-in Dodowa consume only treated, packaged water, but many drink the piped water and/or that obtained from bores and wells, and neither the survey nor open-ended interviews indicated a change in this regard before and after the GWCL shifted to supplying 'Kpong water'. That $80 \%$ of respondents did not treat their water at home indicates that few are aware of health implications or are able to take informed decisions regarding water sources at hand, or the need-or how-to treat water before consuming it.

From a groundwater quality perspective, bedrock geochemistry and anthropogenic pollutants have a potentially negative effect on drinking water safety. Nitrate and other microbiological pollution are common under cities, arising from leaking latrines and sewers, open defecation sites and generally inadequate sanitation solutions. Land use planning, integrated with water supply management, needs to take into account the resilience of land and aquifer characteristics to anthropogenic influence (Lerner and Harris 2009).

To improve well-being and health, water security and resilience, and the trust residents place in their local water sources, this is an important topic to address. Provisioning of water is an obligation of the state to fulfill the human right to safe drinking water. The GWCL and SODA, as proxies of the state, have mandates and responsibilities to provide water, and for planning of the short- and long-term sustainability of available water resources. In times and places of water shortage, poor urban households in particular may resort to self-supply where groundwater is easily accessible. Construction of hand-dug shallow wells represents the transfer of traditional knowledge to cities as a result of 
rural-urban migration but in the urban environment, users must be educated in the need for source protection (Liddle et al. 2015). The government needs to take a proactive stance in this regard, as well as concerning treatment. As much as households in Dodowa are capable of providing for their own water access and ensuring that they are 'resilient' with respect to availability (quantity), they are less so in terms of health and safety issues (quality). Along with many other places characterized by organic growth, this peri-urban area is undergoing change with resulting pressure and impact on its natural resources base, at a pace and degree that make it increasingly difficult for ecosystem services to absorb disturbances, and for human systems to keep up and reorganize. Applying a contextualized resilience lens enables better understanding of what measures should be given priority. It has rightly been found that "[s]achets may be the latest example of how the free market can temporarily bail out local governance failures in basic services provision" (Stoler 2012, p. 1508). But sachets are a solution for quenching thirst, not for increased access to safe water or better equity, improved hygiene, or markedly enhanced resilience to intermittent water supply or drought. In order to not leave anyone behind, planning and decision making must be mindful of how Agenda 2030 marks a new era, fundamentally different from the MDG ambition of "halving the proportion of people without..." in its commitment to realize the human rights of all in a world where the needs of the most vulnerable are met.

\section{Conclusions}

An increasingly unpredictable climate and recurring droughts are now to be considered part of the "new normal" (Pincetl and Hogue 2015)_the rule rather than the exception. For end users of water, particularly poor urban households, resilience is an every-day matter of ensuring access from different sources, for different purposes, in anticipation of inadequate public supply, as well as changes to water availability and quality. This case study of groundwater dependence in an SSA city is not a conventional success story. Rather, it has shown how the capital of Ghana has reduced its flexibility by focusing singlemindedly on expanded raw water intake from the River Volta. As a low-income township on the fringes of the city, Dodowa may have transformed-from being self-sufficient and serving parts of Greater Accra with water from its aquifers to a state where the potentially strategic role of its groundwater resources is poorly recognized in water resources management planning-but the households here have largely remained water secure thanks to the variety of water access possibilities. Being 'served' by the country's public utility means, however, that Dodowa's level of influence is restricted in terms of water sourcing as the GWCL and SODA make decisions in silos without involving each other or the end users.

Foster and MacDonald (2014) stress that the 'water security' dialogue must be better informed about groundwater, and scholars and policy institutes alike emphasize that groundwater is key to achieving a number of interrelated SDGs (cf. Howard 2017). However, given current gaps in the evidence base, the general understanding and acknowledgment of its potentially strategic role is yet limited, with respect to quantity as well as quality issues. Some lessons can be taken out from this case study for the improvement of social-ecological resilience to change.

First, reducing a city's vulnerability to and impact from water insecurity is increasingly important, and it requires a willingness to rethink the business as usual approach. A system can only adapt based on learning how to deal with change and stress. To this end, it is important that planners and decision makers are willing to recognize how end users respond to poor piped water supply, as well as to other types of changes and sudden events. Residents in unplanned urban areas are often forced to handle unpredictable water supply conditions and much can be learnt from embracing their capacity to work around such, through storage, house-holding and conservation, the combining of available sources, and having a Plan B up the sleeve. The government and the public utility should therefore take their cue from how households have developed coping mechanisms by diversifying. In comparison with the situation in many urban centers, peri-urban dwellers-such as those in Dodowa-can more often retain vital household functions with the help of wells and boreholes (and packaged water) even when the piped supply is more inadequate than usual. Further, the wide acceptance of groundwater in Dodowa indicates that it is not regarded as inferior or part of a transient phase while people aspire for piped surface water. Focusing exclusively on water from rivers, lakes, and reservoirs can result in a reduced capability to source water under shifting conditions and disturbances such as droughts. The ground realities offer alternative solutions: For Dodowa and Accra, it seems wise that the water services providers return to abstracting and distributing from existing boreholes, and revive plans to develop groundwater resources in a sustainable manner conjunctively with distributing water via the Kpong. A resilience-based planning approach as proposed here involves seeing groundwater reserves as strategic to augment water utility supply in communities not served and in areas with intermittent utility supply. A positive implication is that the viability of water utilities increases when risks to the raw water base are reduced through diversification. 
Second, groundwater is often-as in Accra-dismissed with a general reference to its low quality and/or health risks. Indeed, deteriorating groundwater reserves need attention. Source protection, involving sanitation and wastewater solutions, is imperative. Treatment of supplied surface waterthe quality of which is subject to decline globally, and in Ghana particularly due to the proliferation of small-scale gold mining-is becoming steadily more advanced. The same reasoning must now also begin to apply to groundwater. In places such as Dodowa, due consideration must be given to the possibilities and advantages of treating the groundwater centrally before distribution through the reticulated network, at the point of abstraction, and/or at pointof-use. In addition, experts and groundwater users need an outlet to voice their concerns, if any, with respect to drinking water safety, and to interlinked sanitation issues. The resilience lens requires a readiness among urban water resources planners to adapt and to regard circumstances in a new light, based on lessons learned and influences from end users. But it also requires wider engagement from stakeholders and the creation of arenas for involvement, a topic outside the scope of this paper.

A third message from this case study concerns the longevity of groundwater resources as part of a natural system, seen in combination with human systems for allocation and conservation decisions. This refers to how availabilitytoday and tomorrow's-is valued in terms of the aquifer's extractive and non-extractive benefits and with respect to the insurance (option) value of its buffer effects. In Dodowa, with growing demand for packaged water in sachets, bottles, and jars, it seems inevitable that the pressure on the available groundwater resources from bottled water companies will increase. Other countries, such as India, have experienced how regulation and control have been insufficient especially when multinational companies start tapping aquifers for profit. Planners and decision makers must understand the importance of managed aquifer recharge to retain the functions of small storage bodies in contexts where this is called for, and regulate abstraction and allocation.

In sum, the administration tasked with the interlinked responsibilities of ensuring water quality and availability face a need to improve system resilience based on interdisciplinary knowledge of water shortage risks and adaptation possibilities. With increasing pressure and impacts from population growth, urbanization, climate change, etc., the ecosystem services that aquifers in (peri-) urban areas provide are fundamental. Among those services are how aquifers function as water reservoirs and buffers. Planners and decision makers have for some time looked at river basins in efforts to secure freshwater for cities, and to varying degrees implemented Integrated Water Resources Management. They are now increasingly taking Nature-Based Solutions into account for urban areas, such as through investments in physical structures that can double as water retention zones during flooding events. The invisible nature and complexity of issues related to hydrogeology and aquifers has meant that groundwater resources do not easily lend themselves to inform policy for the necessary building of resilience. This suggests that groundwater can only gain a role as a strategic resource where an integrated approach to urban water management and governance acknowledges the importance of all available resources, and move away from the focus on large infrastructure and centralized water supply solutions. Fundamentally, in the pursuit of reducing vulnerability the resilience lens tells us to expect the unexpected. In the evermore stressed urban water scenario, diversification is vital to spread risks and improve preparedness.

Acknowledgements The work described in this paper was carried out within the framework of the T-GroUP project, funded by the Department for International Development (DfID), the Economic and Social Research Council (ESRC), and the Natural Environment Research Council (NERC) under the UPGro Programme, NERC Grant Number NE/M008045/1. It draws from a household survey conducted together with Dr George Lutterodt and research assistants Janix Asare, Seth Adjei, and Francis Andorful, and forthcoming research with Dr Jan Willem Foppen.

Open Access This article is distributed under the terms of the Creative Commons Attribution 4.0 International License (http://creativecomm ons.org/licenses/by/4.0/), which permits unrestricted use, distribution, and reproduction in any medium, provided you give appropriate credit to the original author(s) and the source, provide a link to the Creative Commons license, and indicate if changes were made.

\section{References}

Adelana S, Abiye T, Nkhuwa D, Tindimugaya C, Oga M (2008) Urban groundwater management and protection in sub-Saharan Africa. In: Adelana S, Macdonald A (eds) Applied groundwater studies in Africa: IAH selected papers on: vol 13. CRC Press/Balkema, Leiden, pp 231-260

Akple M, Keraita B, Konradsen F, Agbenowu E (2011) Microbiological quality of water from handdug wells used for domestic purposes in urban communities in Kumasi. Ghana Urban Water $\mathbf{J}$ 8:57-64. https://doi.org/10.1080/1573062X.2010.528436

Arku J (2016) Sachet water is not repackaged tap water-FDA. Accra

Braune E, Xu Y (2010) The role of ground water in sub-Saharan Africa. Ground Water 48:229-238. https://doi.org/10.1111/j.1745 $-6584.2009 .00557 . \mathrm{x}$

Buurman J, Mens MJP, Dahm RJ (2017) Strategies for urban drought risk management: a comparison of 10 large cities. Int J Water Resour Dev 33:31-50. https://doi.org/10.1080/07900627.2016 .1138398

Calow RC, MacDonald AM, Nicol AL, Robins NS (2010) Ground water security and drought in Africa: linking availability, access, and demand. Ground Water 48:246-256. https://doi.org/10.1111 j.1745-6584.2009.00558.x

Caputo S, Caserio M, Coles R, Jankovic L, Gaterell MR (2015) Urban resilience: two diverging interpretations. J Urban Int Res Placemaking Urban Sustain 8:222-240. https://doi.org/10.1080/1754 9175.2014.990913 
Chelleri L, Waters JJ, Olazabal M, Minucci G (2015) Resilience tradeoffs: addressing multiple scales and temporal aspects of urban resilience. Environ Urban 27:181-198. https://doi.org/10.1177 $/ 0956247814550780$

Cohen A, Bakker K (2010) Groundwater governance: explaining regulatory non-compliance. Int J Water 5:246-266. https://doi. org/10.1504/IJW.2010.030589

De Wrachien D, Fasso CA (2002) Conjunctive use of surface and groundwater: overview and perspective 1. Irrigation and Drain 51:1-15. https://doi.org/10.1002/ird.43

Esrey SA, Potash JB, Roberts L, Shiff C (1991) Effects of improved water supply and sanitation on ascariasis, diarrhoea, dracunculiasis, hookworm infection, schistosomiasis, and trachoma. Bull World Health Organ 69:609-621

Fewtrell L, Kaufmann RB, Kay D, Enanoria W, Haller L, Colford JM $\mathrm{Jr}$ (2005) Water, sanitation, and hygiene interventions to reduce diarrhoea in less developed countries: a systematic review and meta-analysis. Lancet Infect Dis 5:42-52. https://doi.org/10.1016 /S1473-3099(04)01253-8

Folke C, Carpenter SR, Walker B, Scheffer M, Chapin T, Rockström J (2010) Resilience thinking: integrating resilience. Adaptability Transform Ecol Soc 14:20. https://doi.org/10.5751/ES-0361 $0-150420$

Foster S, Garduño H (2013) Groundwater-resource governance: Are governments and stakeholders responding to the challenge? Hydrogeol J 21:317-320. https://doi.org/10.1007/s10040-0120904-9

Foster S, MacDonald A (2014) The 'water security' dialogue: Why it needs to be better informed about groundwater. Hydrogeol $\mathrm{J}$ 22:1489-1492. https://doi.org/10.1007/s10040-014-1157-6

Foster S, van Steenbergen F (2011) Conjunctive groundwater use: a 'lost opportunity' for water management in the developing world? Hydrogeol J 19:959-962. https://doi.org/10.1007/s10040-0110734-1

Foster S, Tuinhof A, van Steenbergen F (2012) Managed groundwater development for water-supply security in sub-Saharan Africa: investment priorities. Water SA 38:359-366

Franceys F, Gerlach E (eds) (2006) Charging to enter the water shop? DfID KAR 8319. Centre for Water Science, Cranfield University, Cranfield

Garrick D, Hall JW (2014) Water security and society: Risks, metrics, and pathways, vol 39. https://doi.org/10.1146/annurev-environ013012-093817

Ghana Modern (2014) Israel and the Netherlands fund ATMA water project. Modern Ghana, Accra

Ghanaian Chronicle (2008) Government maintains Aqua Vitens deal... to manage water supply in the country. Accra

Government of Ghana (2016) Greenbook Ghana: infrastructure. http ://greenbookghana.com/infrastructure/

Grönwall J (2016) Self-supply and accountability: to govern or not to govern groundwater for the (peri-) urban poor in Accra. Ghana Environ Earth Sci. https://doi.org/10.1007/s12665-016-5978-6

GSS (Ghana Statistical Service) (2014) 2010 Population \& housing census: Shai-Osudoku District analytical report. Accra

GWCL (2016) History of water supply in Ghana. http://www.gwcl .com.gh/pgs/history.php. Accessed 13 May 2016

Hope R, Rouse M (2013) Risks and responses to universal drinking water security Philosophical Transactions of the Royal Society A: mathematical. Phys Eng Sci. https://doi.org/10.1098/rsta.2012 .0417

Howard G (2017) Groundwater research into policy within the context of Africa \& the SDGs. DFID. http://www.iah-british.org/wp-cont ent/uploads/2017/11/Howard_Ineson2017.pdf. Accessed 1 Dec 2017
Knüppe K, Pahl-Wostl C (2011) A framework for the analysis of governance structures applying to groundwater resources and the requirements for the sustainable management of associated ecosystem services. Water Resour Manag 25:3387-3411. https://doi. org/10.1007/s11269-011-9861-7

Kooy M (2014) Developing informality: the production of Jakarta's urban waterscape. Water Alternatives 7:35-53

Kortatsi BK (1994) Groundwater utilization in Ghana. In: Future groundwater at risk, Helsinki, June 1994. IAHS

Kortatsi BK (2006) Hydrochemical characterization of groundwater in the Accra plains of Ghana. Environ Geol 50:299-311. https://doi. org/10.1007/s00254-006-0206-4

Lapworth DJ, Nkhuwa DCW, Okotto-Okotto J, Pedley S, Stuart ME, Tijani MN, Wright J (2017) Urban groundwater quality in subSaharan Africa: current status and implications for water security and public health Hydrogeol J 1-24 https://doi.org/10.1007/s100 40-016-1516-6

Lerner DN, Harris B (2009) The relationship between land use and groundwater resources and quality. Land Use Policy 26(Supplement 1):S265-S273. https://doi.org/10.1016/j.landusepol.2009 .09 .005

Liddle ES, Mager SM, Nel EL (2015) The suitability of shallow hand dug wells for safe water provision in sub-Saharan Africa: lessons from Ndola, Zambia. Appl Geogr 57:80-90. https://doi. org/10.1016/j.apgeog.2014.12.010

Liddle ES, Mager SM, Nel E (2016) The importance of communitybased informal water supply systems in the developing world and the need for formal sector support. Geogr J 182:85-96. https://doi. org/10.1111/geoj.12117

MacDonald AM, Bonsor HC, Dochartaigh BÉÓ, Taylor RG (2012) Quantitative maps of groundwater resources in Africa. Environ Res Lett. https://doi.org/10.1088/1748-9326/7/2/024009

Machdar E, van der Steen NP, Raschid-Sally L, Lens PNL (2013) Application of quantitative microbial risk assessment to analyze the public health risk from poor drinking water quality in a low income area in Accra Ghana. Sci Total Environ 449:134-142. http s://doi.org/10.1016/j.scitotenv.2013.01.048

Mekonnen MM, Hoekstra AY (2016) Four billion people facing severe water scarcity. Sci Adv

Muller M (2007) Adapting to climate change: water management for urban resilience. Environ Urban 19:99-113. https://doi. org/10.1177/0956247807076726

Narain V (2014) Whose land? Whose water? Water rights, equity and justice in a peri-urban context. Local Environ 19:974-989. http s://doi.org/10.1080/13549839.2014.907248

Nieswand GH, Granstrom ML (1971) A chance-constrained approach to the conjunctive use of surface waters and groundwaters. Water Resour Res 7:1425-1436. https://doi.org/10.1029/WR007i006p01 425

Norely N (2006) Ghana: water coy commissions 5 mechanised boreholes to ease Adenta water problems. Accra

OECD (2017) Groundwater allocation: managing growing pressures on quantity and quality. OECD Publishing, Paris. https://doi. org/10.1787/9789264281554-en

Okotto L, Okotto-Okotto J, Price H, Pedley S, Wright J (2015) Socioeconomic aspects of domestic groundwater consumption, vending and use in Kisumu, Kenya. Appl Geogr 58:189-197. https://doi. org/10.1016/j.apgeog.2015.02.009

Owusu K, Teye JK (2014) Supplementing urban water supply with rainwater harvesting in Accra, Ghana. Int J Water Resour Dev. https://doi.org/10.1080/07900627.2014.927752

Padowski JC, Carrera L, Jawitz JW (2016) Overcoming urban water insecurity with infrastructure and institutions. Water Resour Manage 30:4913-4926. https://doi.org/10.1007/s11269-016-1461-0 
Peloso M, Morinville C (2014) 'Chasing for water': everyday practices of water access in peri-urban Ashaiman, Ghana. Water Alternatives 7:121-139

Pincetl S, Hogue TS (2015) California's new normal? Recurring drought: addressing winners and losers. Local Environ 20:850854. https://doi.org/10.1080/13549839.2015.1042778

Qureshi ME, Reeson A, Reinelt P, Brozović N, Whitten S (2012) Factors determining the economic value of groundwater. Hydrogeol $\mathrm{J}$ 20:821-829. https://doi.org/10.1007/s10040-012-0867-x

Rudestam K, Langridge R (2014) Sustainable yield in theory and practice: bridging scientific and mainstream vernacular. Groundwater 52:90-99. https://doi.org/10.1111/gwat.12160

Sahuquillo A (1985) Groundwater in water resources planning: conjunctive use. Water Int 10:57-63. https://doi.org/10.1080/0250 8068508686308

Sahuquillo A (2002) Conjunctive use of surface water and groundwater. In: L S (ed) UNESCO encyclopedia of life-support systems. EOLSS, Cambridge, UK

Scanlon B, Reedy R, Faunt C, Pool D, Uhlman K (2016) Enhancing drought resilience with conjunctive use and managed aquifer recharge in California and Arizona. Environ Res Lett 11:035013

Stoler J (2012) Improved but unsustainable: accounting for sachet water in post-2015 goals for global safe water. Trop Med Int Health 17:1506-1508. https://doi.org/10.1111/j.1365-3156.2012.03099.x

Stoler J, Weeks JR, Fink G (2012) Sachet drinking water in Ghana's Accra-Tema metropolitan area: past, present, and future. J Water Sanit Hyg Dev 2:223-240. https://doi.org/10.2166/washdev.2012 .104

Stoler J, Tutu RA, Ahmed H, Frimpong L, Bello M (2014) Sachet water quality and brand reputation in two low-income urban communities in Greater Accra, Ghana. Am J Trop Med Hyg 90:272-278. https://doi.org/10.4269/ajtmh.13-0461
Stoler J, Tutu RA, Winslow K (2015) Piped water flows but sachet consumption grows: the paradoxical drinking water landscape of an urban slum in Ashaiman, Ghana. Habitat Int 47:52-60. https:// doi.org/10.1016/j.habitatint.2015.01.009

Tandon SA, Kolekar N, Kumar R (2014) Water and energy footprint assessment of bottled water industries in India. Nat Resour 5:68 72. https://doi.org/10.4236/nr.2014.52007

Taylor RG et al (2013) Ground water and climate change. Nat Clim Change 3:322-329. https://doi.org/10.1038/nclimate1744

UN DESA (United Nations Department of Economic and Social Affairs) (2015) World urbanization prospects: the 2014 revision (ST/ESA/SER.A/366)

UN-Habitat (2016) Urbanization and development: emerging futures: world cities report 2016. UN-Habitat, Nairobi

van Rooijen DJ, Spalthoff D, Raschid-Sally L (2008) Domestic water supply in Accra: how physical and social constraints to planning have greater consequences for the poor. In: 33rd WEDC international conference, Accra, Ghana

Vinorkor M-A, Afari-Mintah J (2008) Water: Accra to benefit from 13 Boreholes. Accra

WHO (World Health Organization) (2003) Total dissolved solids in drinking-water: background document for development of WHO guidelines for drinking-water quality. World Health Organization, Geneva

Wright J, Dzodzomenyo M, Fink G, Wardrop NA, Aryeetey GC, Adanu RM, Hill AG (2016) Subsidized sachet water to reduce diarrheal disease in young children: a feasibility study in Accra, Ghana. Am J Trop Med Hyg 95:239-246. https://doi.org/10.4269/ajtm h. 15-0854 